\title{
THE GENUS MANSONELLA (SYN. TETRAPETALONEMA) : A new classification
}

\author{
M. L. EBERHARD and T. C. ORIHEL
}

SUMMARY. Mansonella has been established as a valid genus, and Tetrapetalonema synonymized with it. Comparative morphological studies have resulted in the restructuring of the Mansonella group. The genus is characterized by the following features : cuticular preesophageal ring absent ; esophagus slender, poorly differentiated ; female tail with four terminal papillae ; caudal papillae in male typically clustered around cloaca; and, microfilariae without sheath. Twenty-four species are assigned to the genus Mansonella. Five subgenera are proposed to accomodate these species. The subgeneric groups are distinguished principally on morphological criteria, although host range and geographical distribution are considered. The following systematic classification is proposed :

- Mansonella (Mansonella) subgen. n., to accomodate those species which have the following morphological features : cephalic extremity with dorsoventral orientation ; male tail with tip flattened dorsoventrally; vulva in midesophageal region; and microfilariae without nuclei extenting to tip of tail. Type species is $M$. (M.) ozzardi.

- Mansonella (Tupainema) subgen. n., to accomodate the single species $M$. dunni with the following characters : cephalic extremity with lateral orientation and body constricted to form cephalic extremity in shape of hemisphere narrower than body behind it; tip of male tail not flattened dorsoventrally ; vulva at or posterior to base of esophagus ; and, microfilariae without nuclei to tip of tail.

- Mansonella (Esslingeria) comb. n., to accomodate those species with the following characters : cephalic extremity with lateral orientation; male tail flattened dorsoventrally at tip or not; vulva in midesophageal region; and, microfilariae with nuclei to tip of tail. Type species is M. (E.) perstans.

- Mansonella (Tetrapetalonema) comb. n., to accomodate those species with the following characters : cephalic extremity with dorsoventral orientation or with body constricted to form cephalic extremity in shape of hemisphere narrower than body behind it; male tail not flattened at tip ; vulva in midesophageal region ; and, microfilariae with nuclei to tip of tail. Type species is $M$. (T.) marmosetae.

- Mansonella (Sandnema) comb. n., to accomodate those species with the following characters : cephalic extremity rounded, not oriented along lateral or median axis ; tip of male tail not flattened; caudal papillae on male tail not clustered around cloaca; vulva near base of esophagus; and, microfilariae with nuclei to tip of tail. Type species is $M$. (S.) digitata.

The International Collaboration in Infectious Diseases Research (ICIDR) Program, Tulane University Medical Center, New Orleans, Louisiana 70112 and Delta Regional Primate Research Center Tulane University Covington, Louisiana 70433.

Accepté le 5 décembre 1983 . 


\section{Le genre Mansonella (syn. Tetrapetalonema) : une classification nouvelle}

RÉSUMÉ. La validité du genre Mansonella a été établie précédemment et Tetrapetalonema mis en synonymie avec ce genre. Des études morphologiques comparées ont abouti à des modifications de la systématique du groupe Mansonella. Le genre possède les caractères suivants : anneau cuticulaire préœsophagien absent; œsophage mince, peu différencié ; queue de la femelle avec quatre languettes terminales ; papilles caudales du mâle typiquement groupées autour du cloaque, et microfilaires sans gaine. Vingt-quatre espèces sont situées dans le genre Mansonella. Cinq sous-genres sont proposés. Ils sont principalement définis par des critères morphologiques, mais le spectre d'hôtes et la répartition géographique sont également considérés. Nous proposons les coupures systématiques suivantes :

- Mansonella (Mansonella) n. sub. gen,. pour les espèces qui possèdent les caractères morphologiques suivants : extrémité céphalique avec orientation dorso-ventrale; pointe caudale du mâle aplatie dorso-ventralement ; vulve au niveau de la région moyenne de l'œsophage et noyaux des microfilaires ne s'étendent pas jusqu'à l'extrémité de la queue. Eepèce type : $M$. (M.) ozzardi.

- Mansonella (Tupainema) n. sub. gen., pour la seule espèce, $M$. dunni, qui a les caractères suivants : extrémité céphalique avec orientation latérale; constriction antérieure du corps séparant l'extrémité céphalique de forme hémisphérique et étroite du reste du corps plus épais; pointe caudale du mâle non aplatie dorso-ventralement vulve au niveau de, ou postérieure à la base de l'œsophage, et noyaux des microfilaires ne s'étendant pas jusqu'à l'extrémité de la queue.

- Mansonella (Esslingeria) n. comb., pour les espèces ayant les caractères suivants : extrémité céphalique avec orientation latérale ; queue du mâle aplatie dorso-ventralement, à pointe caudale présente ou non ; vulve au niveau de la région moyenne de l'œsophage, et noyaux des microfilaires s'étendant jusqu'à l'extrémité de la queue. Espèce type : $M$. (E.) perstans.

- Mansonella (Tetrapetalonema) n. comb., pour les espèces ayant les caractères suivants : extrémité céphalique avec orientation dorso-ventrale, ou avec constriction antérieure du corps séparant l'extrémité céphalique de forme hémisphérique et étroite du reste du corps plus épais ; queue du mâle non aplatie à l'extrémité ; vulve au niveau de la région moyenne de l'œsophage, et noyaux des microfilaires s'étendant jusqu'à l'extrémité de la queue. Espèce type:M. (T.) marmosetae.

- Mansonella (Sandnema) n. comb., pour les espèces ayant les caractères suivants : extrémité céphalique arrondie, non orientée suivant l'axe latéral ou l'axe médian; queue du mâle non aplatie à l'extrémité ; papilles caudales du mâle non groupées autour du cloaque; vulve près de la base de l'œsophage, et noyaux des microfilaires s'étendant jusqu'à l'extrémité de la queue, Espèce type : $M$. (S.) digitata.

\section{Introduction}

The genus Mansonella was created by Faust in 1929 to accommodate the species Filaria ozzardi of man. Shortly thereafter, he also erected the genus Tetrapetalonema to accept a new species of filaria from a neotropical monkey (Faust, 1935). The genus Tetrapetalonema was accepted as a valid genus by some workers (Yeh, 1957 ; Dunn and Lambrecht, 1963; Mullin and Orihel, 1972) but rejected by others (Chabaud and Anderson, 1959). Recently, however, the genus became recognized and accepted as a valid taxonomic group (Chabaud and Bain, 1976; Anderson 
and Bain, 1976). On the other hand, the features and validity of the genus Mansonella remained uncertain.

The redescription of Mansonella ozzardi by Orihel and Eberhard (1982) led to the synonymy of the genus Tetrapetalonema with Mansonella. During the course of this work, it became evident that a certain amount of reorganization and redefinition of the subgenera of Tetrapetalonema, as proposed by Chabaud and Bain (1976), was necessary. The classification proposed in the present study is based on a comparative morphological analysis of the parasites, the spectrum of hosts they parasitize, and their geographical distribution. Relationship within and between subgenera are discussed.

\title{
A - Definition of the genus Mansonella
}

The genus Mansonella is relatively simple to define, since the group is homogeneous in most regards ; yet, it appears to be specialized and highly evolved as well. The genus was characterized by Orihel and Eberhard (1982) on the same basic morphological features as proposed by Chabaud and Bain (1976) for the genus Tetrapetalonema, with one exception. The morphology of the microfilaria, particularly with regard to the arrangement of nuclei in the tail, has been found to be especially useful in the delineation of the subgenera and has been incorporated into the present scheme. The generic definition provided below is based on that of Orihel and Eberhard (1982).

\author{
Massonella (Faust, 1929) \\ (Syn. Tetrapetalonema Faust, 1935)
}

\section{Definition}

Onchocercidae (Leiper, 1911) Chabaud and Anderson, 1959; Onchocercinae Leiper, 1911. Adult worms small, slender, typically inhabit subcutaneous tissues. Body of uniform diameter throughout most of length ; prominent annular swellings characteristically present on the anterior extremity. Preesophageal cuticular ring absent. Esophagus weakly developed, narrow, not conspicuously divided into muscular and glandular portions. Caudal end of female typically bears four terminal papillae. Caudal papillae in male characteristically clustered around cloaca ; precloacal papillae absent or mixed with pericloacal papillae. Gubernaculum absent. Spicules unequal, dissimilar, moderately long, slender and of simple structure. Microfilaria without sheath. Type species, $M$. ozzardi.

\section{B - Description of the subgenera}

The genus Mansonella, as presented here, is composed of five subgenera which are clearly distinguished on morphological criteria. Within certain subgenera, the host range and geographical distribution are uniform, while in others, considerable heterogeneity exists both in the hosts parasitized and in geographical distribution. 
I - Mansonella (Mansonella) subgen. $\mathrm{n}$.

(Plate I, fig. 1-9; Plate II, fig 1-6)

Description: With all characters of the genus. Cephalic extremity with major axis dorsoventral ; cephalic extremity neither compressed nor narrower than body behind it. Male tail flattened dorsoventrally near tip. Spicules moderately long; spicule ratio 2.6 to 3.0. Vulva in midesophageal region. Microfilaria without nuclei to tip of tail. Parasites of man, rodents and carnivores.

M. (M.) ozzardi (Manson, 1897) type species; adults described by Orihel and Eberhard, 1982. Host : man (Homo) ; Central and South America, Caribbean Islands.

M. (M.) llewellyni (Price, 1962). Host : raccoon (Procyon); North America.

M. (M.) interstitium (Price, 1962). Host : squirrel (Sciureus); North America.

M. (M.) akitensis (Uni, 1982). Host : bear (Ursus) ; Japan.

II - Mansonella (Tupainema) subgen. n. (Plate III, fig. 1-6)

Description: With all characters of genus. Cephalic extremity with major axis lateral ; cephalic extremity compressed, narrower than body behind it. Male tail not dorsoventrally compressed. Spicules moderately long, spicule ratio 2.8. Vulva at or posterior to base of esophagus. Microfilaria without nuclei to tip of tail. Parasites of tree shrews in S.E. Asia.

M. (T.) dunni (Mullin and Orihel, 1972) type species. Host : tree shrew (Tupaia); S.E. Asia.

III - Mansonella (Esslingeria) comb. n. (Plate IV, fig. 1-7)

Description: With all characters of the genus. Cephalic extremity with major axis lateral ; cephalic extremity neither compressed nor narrower than body behind it. In dorsoventral view, constricted neck-like region may be present. Male tail may or may not be flattened dorsoventrally. Spicules long, spicule ratio 2.3 to 4.7. Vulva in midesophageal region. Microfilariae with nuclei to tip of tail. Parasites of man, African anthropoid apes and South American rodents.

M. (E.) perstans (Manson, 1981) type species; redescribed by Chabaud, 1952. Host : man (Homo) ; Africa, Central and South America.

M. (E.) streptocerca (Macfie and Corson, 1922) adults described by Peel and Chardome, 1946, 1947 and Gardiner et al., 1979. Host : man (Homo), chimpanzee (Pan), gorilla (Gorilla) ; Africa.

M. (E.) vanhoofi (Peel and Chardome, 1946) redescribed by Chabaud and Rousselot, 1956. Host : chimpanzee (Pan), gorilla (Gorilla) ; Africa.

M. (E.) rodhaini (Peel and Chardome, 1947). Host : chimpanzee (Pan), man (Homo) ; Africa.

M. (E.) leopoldi (Berghe, Chardome and Peel, 1964). Host : gorilla (Gorilla); Africa. 
M. (E.) rotundicapita Eberhard et al., 1984. Host : capybara (Hydrochoerus); South America.

M. (E.) longicapita Eberhard et al., 1984. Host : capybara (Hydrochoerus) ; South America.
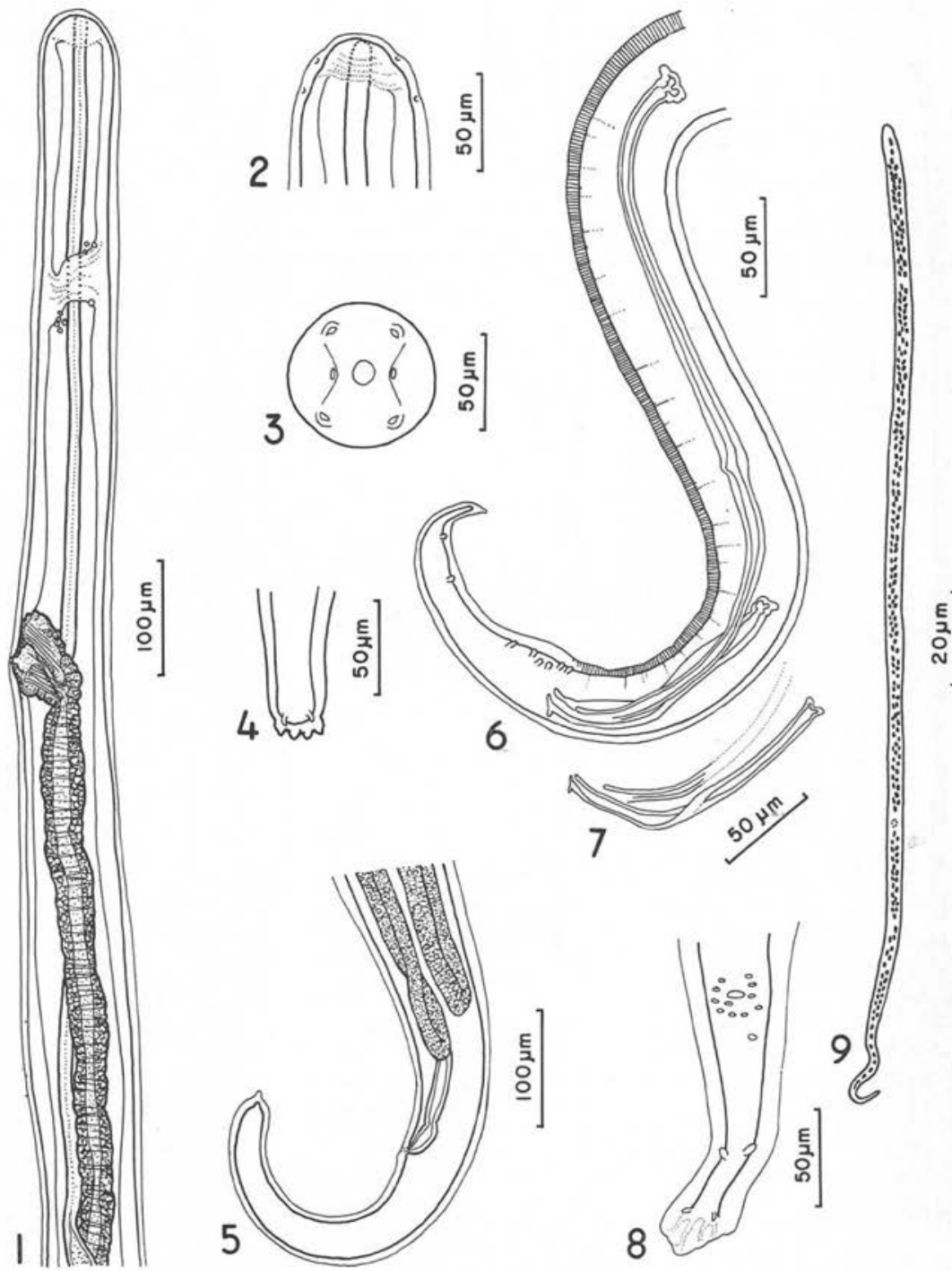

Plate I, figures I to 9. - Mansonella (Mansonella) ozzardi subgen. n. I. Female anterior end, lateral view (after Orihel and Eberhard, 1982). 2. Female anterior extremity, lateral view (after Orihel and Eberhard, 1982). 3. Female anterior extremity, en face (original). 4. Tip of female tail, ventral view (after Orihel and Eberhard, 1982). 5. Female posterior end, lateral view (after Orihel and Eberhard, 1982). 6. Male posterior end, lateral view (after Orihel and Eberhard, 1982). 7. Right spicule and distal end of left spicule to show details, lateral view (after Orihel and Eberhard, 1982). 8. Male tail, ventral view (after Orihel and Eberhard, 1982). 9. Microfilaria fixed in $2 \%$ formalin and stained with hematoxylin (original). 



4 

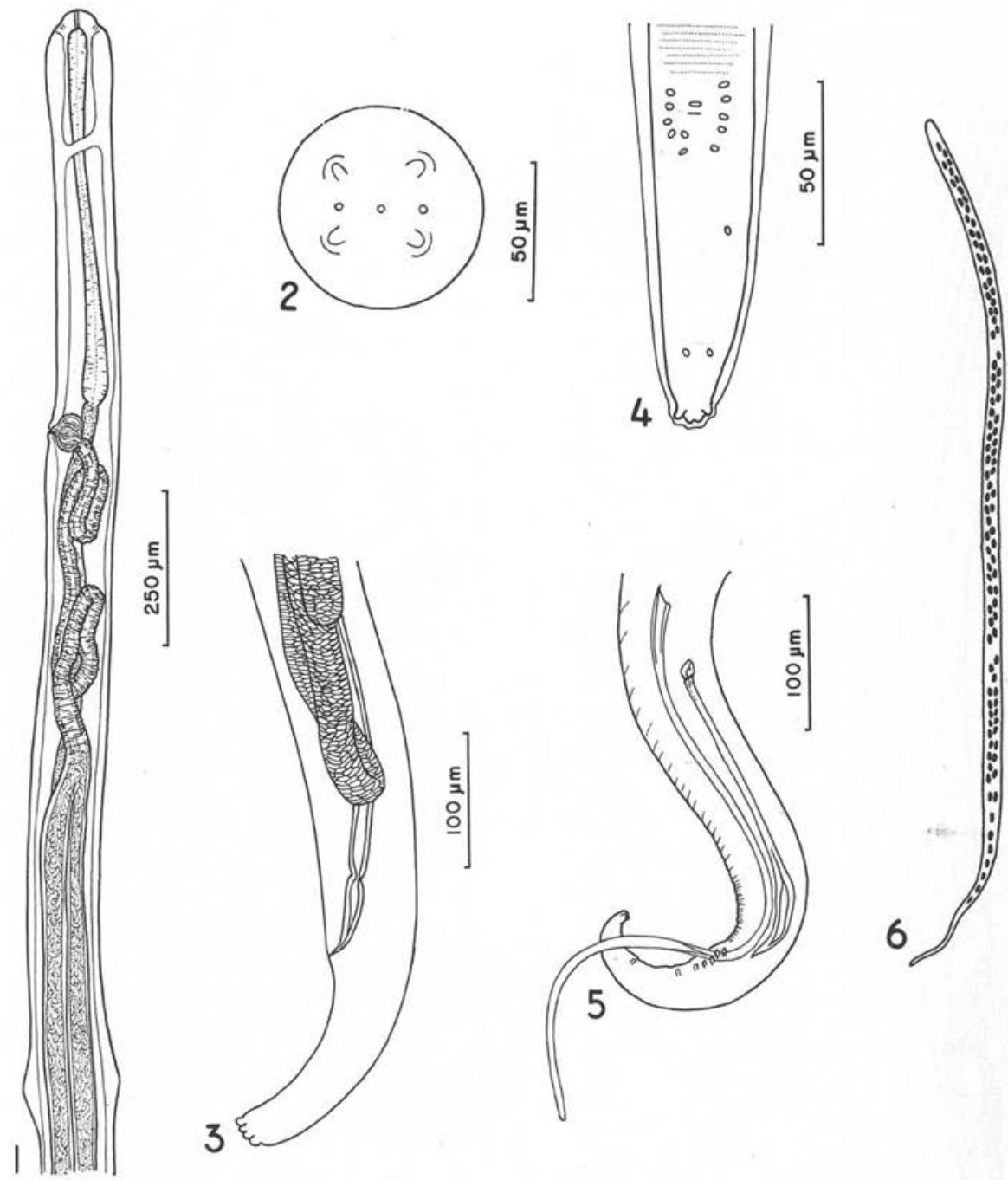

틈

Plate III, figures I to 6. - Mansonella (Tupainema) dunni subgen. n. et comb. n. I. Female anterior end, lateral view (after Mullin and Orihel, 1972). 2. Female anterior extremity, en face (original). 3. Female posterior end, lateral view (after Mullin and Orihel, 1972). 4. Male tail, ventral view (original). 5. Male posterior end, lateral view (after Mullin and Orihel, 1972). 6. Microfilaria fixed in $2 \%$ formalin and stained with hematoxylin (original). 

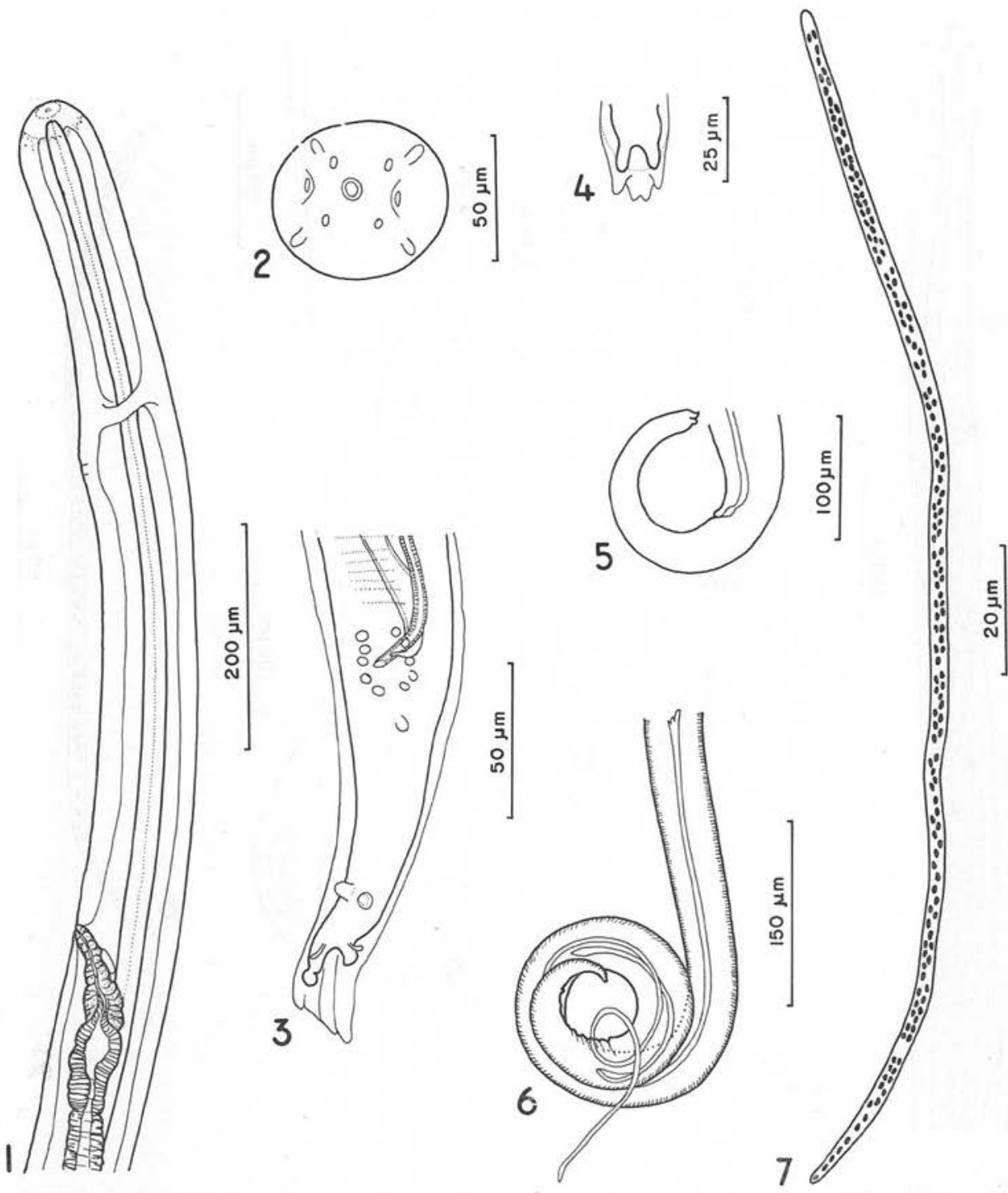

Plate IV, figures I to 7.-Mansonella (Esslingeria) perstans comb. n. I. Female anterior end, lateral view (after Chabaud, 1952). 2. Female anterior extremity, en face (after Chabaud, I952). 3. Male tail, ventral view (after Chabaud, I952). 4. Tip of female tail, ventral view (after Chabaud, 1952). 5. Female posterior end, lateral view (modified from Chabaud, 1952). 6. Male posterior end, lateral view (after Chabaud, 1952). 7. Microfilaria fixed in $2 \%$ formalin and stained with hematoxylin (original). 
IV - Mansonella (Tetrapetalonema) comb. n. (Plate V, fig. 1-6)

Description: With all characters of genus. Cephalic extremity with major axis dorsoventral, or, cephalic extremity compressed, narrower than body behind it. Male tail not flattened dorsoventrally. Spicules very short to long, spicule ratio 1.6 to 4.8 . Vulva generally in midesophageal region. Microfilariae with nuclei extending to tip of tail. Parasites of platyrrhine (neotropical) primates.

M. (T.) marmosetae (Faust, 1935) type species. Host : squirrel monkey (Saimiri), marmoset (Saguinus), spider monkey (Ateles); Central and South America.

M. (T.) atelensis (McCoy, 1935). Host : spider monkey (Ateles); Central America.

M. (T.) panamensis (McCoy, 1936) adults described by Esslinger, 1979. Host : cebus monkey (Cebus), owl monkey (Aotus), marmoset (Saguinus); Central and South America.

M. (T.) parvum (McCoy, 1936). Host : cebus monkey (Cebus), squirrel monkey (Saimiri) ; Central America.

M. (T.) obtusa (McCoy, 1936) adults described by Esslinger, 1966. Host : cebus monkey (Cebus) ; Central and South America.

M. (T.) tamarinae (Dunn and Lambrecht, 1963). Host : marmoset (Saguinus); South America.

M. (T.) barbascalensis (Esslinger and Gardiner, 1974). Host : owl monkey (Aotus); South America.

M. (T.) mystaxi (Eberhard, 1978). Host : marmoset (Saguinus); South America.

M. (T.) saimiri (Esslinger, 1981). Hcst : squirrel monkey (Saimiri); South America.

M. (T.) colombiensis (Esslinger, 1982). Host : squirrel monkey (Saimiri), cebus monkey (Cebus) ; South America.

[M. (T.) zakii (Nagaty, 1935) reconsidered by Esslinger and Gardiner, 1974.] Considered a species inquirenda in the present study.

V - Mansonella (Sandnema) comb. n.

(Plate VI, fig. 1-7)

Description: With characters of genus, except caudal papillae in male not clustered around cloaca but distributed along tail. Cephalic extremity rounded; papillae disposed in square, not drawn out along the lateral or median axis. Male tail not flattened dorsoventrally. Spicules of moderate length, spicule ratio 2.3 to 2.6. Vulva in posterior esophageal region. Microfilariae with nuclei to tip of tail. Parasites of Asian primates and insectivores.

M. (S.) digitata (Chandler, 1929) type species; reviewed by Sandground, 1938. Host : macaque monkeys (Macaca); Asia.

M. (S.) sunci (Sandground, 1933). Host : musk shrew (Suncus); China. 

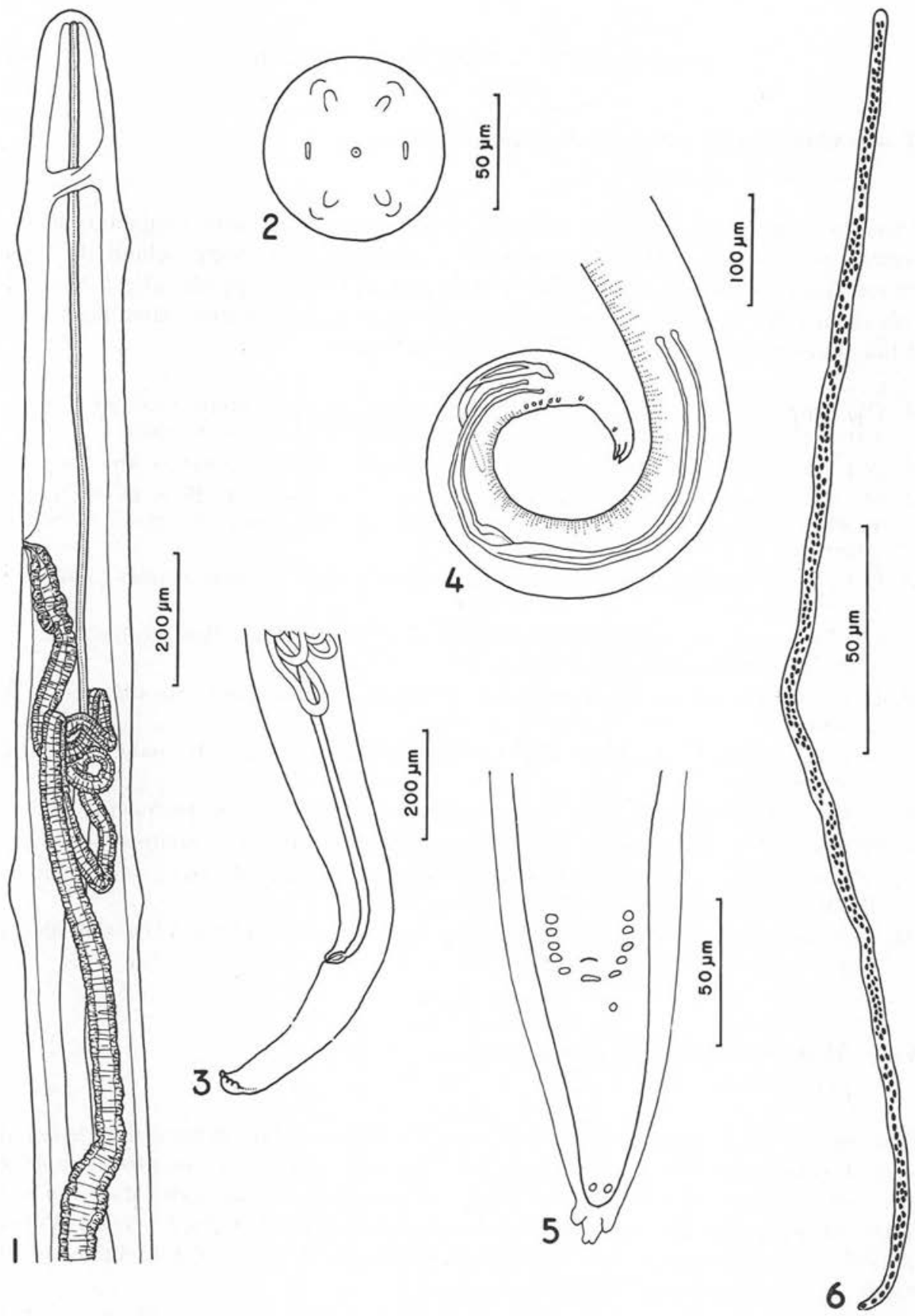

Plate V, figures I to 6. - Mansonella (Tetrapetalonema) marmosetae comb. n. I. Female anterior end; lateral view (original). 2. Female anterior extremity, en face (original). 3. Female posterior end, lateral view (original). 4. Male posterior end, lateral view (original). 5. Male tail, ventral view (original). 6. Microfilaria fixed in $2 \%$ formalin and stained with hematoxylin (original). 

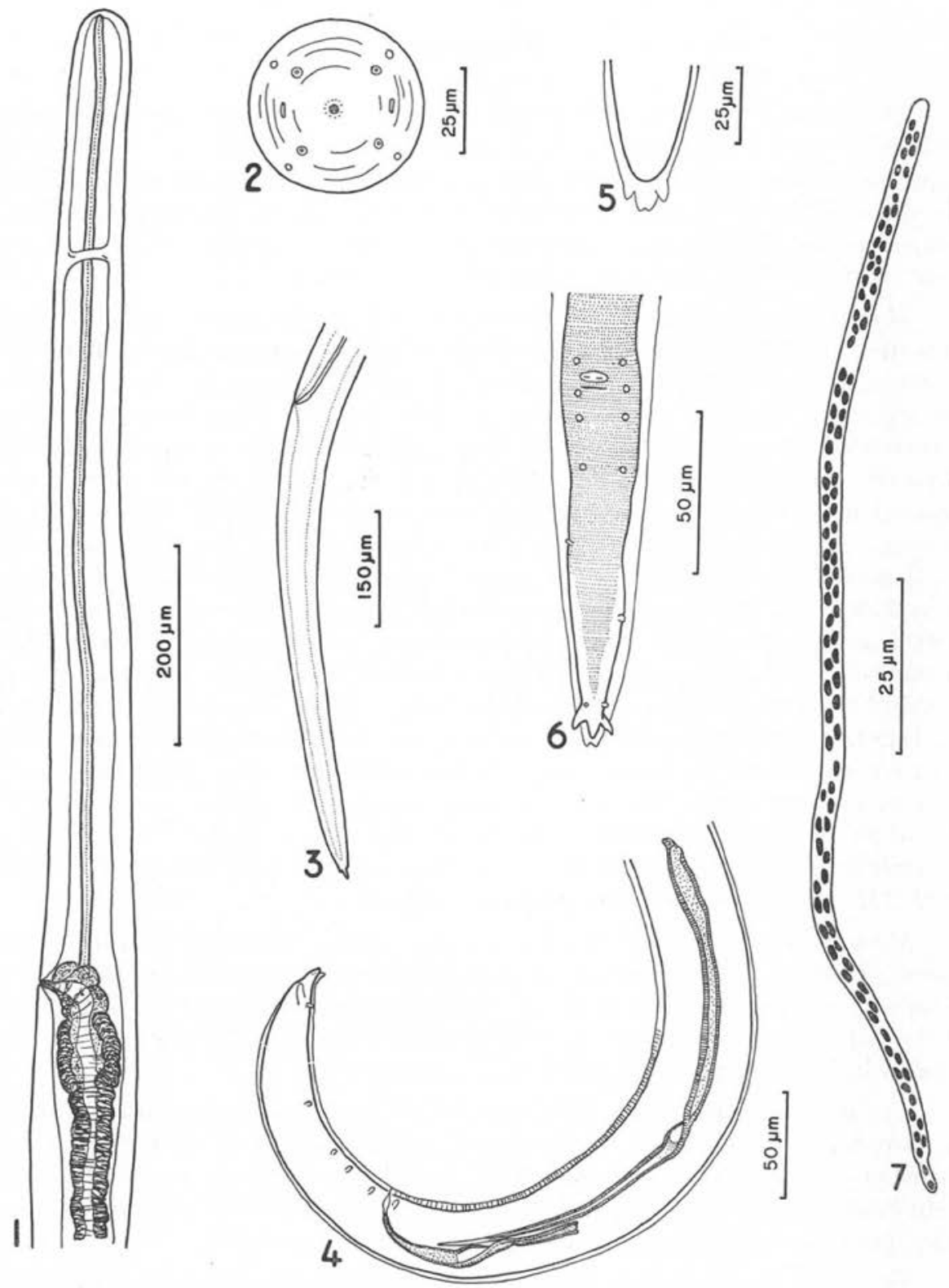

Plate VI, figures I to 7. - Mansonella (Sandnema) digitata comb. n. I. Female anterior end, lateral view (original). 2. Female anterior extremity, en face (after Sandground, I938). 3. Female posterior end, lateral view (original). 4. Male posterior end, lateral view (after Sandground, 1938). 5. Tip of female tail, ventral view (original). 6. Male tail, ventral view (after Sandground, 1938). 7. Microfilaria fixed in $2 \%$ formalin and stained with hematoxylin (original). 


\section{Discussion}

The genus Mansonella, of uncertain status for many years, has been revived and revised with the redescription of $M$. ozzardi (Orihel and Eberhard, 1982). It was apparent that the genus Tetrapetalonema was synonymous with Mansonella. However, the redescription of $M$. ozzardi necessitated revisions in the taxonomic position of certain species. In order to accommodate these changes, two new subgeneric groups were created - M. (Mansonella) and M. (Tupainema).

Mansonella (Mansonella) is the most uniform subgenus, morphologically. However, in terms of its host preferences it is one of the most diverse. It includes four species, i.e., $M$. ozzardi, M. llewellyni, M. interstitium and M. akitensis. Two of the species $M$. llewellyni and $M$. interstitium were originally included in the subgenus Tetrapetalonema by Chabaud and Bain (1976); M. akitensis was added by Uni (1983). However, the morphology of the male tail and the microfilaria tail warrant their removal from Tetrapetalonema and their current placement. Uni (1983) noted the close morphological similarity between $M$. akitensis and the two American species $M$. llewellyni and $M$. interstitium. A feature he had used to differentiate $M$. akitensis from both $M$. llewellyni and $M$. interstitium was the position of the vulva in relation to the base of the esophagus. However, an examination of type material and specimens in our collections revealed that differences existed between our accounts and the descriptions Price (1962) provided for M. llewellyni and M. interstitium. In particular, the length of the esophagus in both species was found to be about three times longer than reported by Price. Consequently, in the female, the vulva lies anterior to the base of the esophagus. Nevertheless, other morphological features, including the size of the microfilariae, readily differentiate these three species. The presence of $M$. akitensis in bears in Japan is of special interest in that it extends the distribution of $M$. (Mansonella) outside the western hemisphere.

Mansonella (Tupainema) has only a single species, $M$. dunni. This species was placed originally in the subgenus (Tetrapetalonema) by Chabaud and Bain (1976). However, based on the orientation of the cephalic extremity and the morphology of the tail in the microfilariae, $M$. (Tupainema) is clearly distinct from M. (Tetrapetalonema) and warrants placement in a separate group.

The subgenera $M$. (Mansonella) and $M$. (Tupainema) are remarkably similar in microfilarial morphology. The absence of nuclei in the tip of the tail clearly sets these two subgenera apart from the others. On the other hand, the two can be readily distinguished in the adult stage on the basis of the orientation of the cephalic extremity, position of the vulva and the morphology of the male tail.

The $M$. (Tetrapetalonema) group has the most restricted host range in that all species are parasitic in platyrrhine monkeys. It should be noted that many of the species which constitute this subgenus are encountered in a much broader range of neotropical primates than indicated in the subgeneric description. The validity of Mansonella (=Parlitomosa) $z a k i i$, previously placed in this subgenus, is questionable. 
It was described by Nagaty (1935) from specimens recovered from a marmoset which died in the zoological gardens near Cairo, Egypt. However, according to Esslinger and Gardiner (1974) the types and all other specimens of zakii have been lost. Moreover, this species has apparently not been encountered since the original report. Consequently, we consider it a species inquirenda for the present.

Mansonella (Esslingeria), although a morphologically uniform group, does exhibit diversity in spicule size and tail structure. In perstans and leopoldi, the spicules are extremely long (left spicule $800-900 \mu \mathrm{m}$; right spicule $200 \mu \mathrm{m}$ ) whereas in streptocerca, rodhaini, rotundicapita, and longicapita they are relatively short (left spicule $300-460 \mu \mathrm{m}$; right spicule $120-160 \mu \mathrm{m})$. In one species, vanhoofi, the spicules are intermediate in size (left spicule $550 \mu \mathrm{m}$; right spicule $130 \mu \mathrm{m}$ ). The male tail in perstans, rotundicapita and longicapita is dorsoventrally flattened, whereas in streptocerca it is not.

Mansonella (Sandnema) is the most poorly characterized of the sugbeneric groups. It is composed of only two species, $M$. digitata and $M$. sunci; the latter is poorly described. Study of museum specimens and others in the authors' collections indicate that these two species are virtually identical in mensural and morphological features. Further study of additional specimens of $M$. sunci will be necessary before the validity of the species can be determined. The Sandnema group is distinct, morphologically, from the other subgenera in several features. Grossly, digitata and sunci, are the largest in the genus, being three to four times larger (both length and breadth) than any others. They are robust worms which taper markedly at both extremities. In contrast, others in the genus typically taper only slightly at the extremities. Additionally, the absence of migration of the cephalic papillae along the lateral or dorsoventral axis and the absence of papillae clustered around the cloaca serve to distinguish $M$. (Sandnema) from the other subgenera. It is possible that in the future, $M$. (Sandnema) will be elevated to the generic level.

The genus Mansonella is a relatively homogeneous group. Morphological features, including the absence of a preesophageal cuticular ring, the weakly developed esophagus, spicule morphology, absence of a gubernaculum, arrangement of pericloacal papillae, and unsheathed microfilariae are constant throughout the genus and suggest a highly evolved form.

The genus also has a common biological feature in its vector requirements. In all species in which the life cycle is known, development occurs in species of Culicoides (Sharp, 1928 ; Buckley, 1934 ; Chardome and Peel, 1949 ; Lowrie et al., 1978 ; Yates et al., 1982). The only exception to this is $M$. ozzardi, which also develops in some species of Simulium in the Amazon Basin. However, there is firm evidence that Culicoides can or do serve as vectors in this area (Lowrie et al., 1982 ; Tidwell and Tidwell, 1982), suggesting that Simulium may be a secondarily adapted vector.

Acknowledgements. This study was supported by program project grant AI 1631503 (ICIDR) NIAID/NIH, and grant RR00164, Division of Research Resources, National Institutes of Health, Bethesda. 


\section{REFERENCES}

I. Anderson R. C., Bain O. : No. 3. Keys to genera of the order Spirurida. Part 3. Diplotriaenoidea, Aproctoidea and Filarioidea. In : CIH Keys to the Nematode Parasites of Vertebrates. Commonwealth Agricultural Bureaux, Farnham Royal, England, 1976, $5^{8}$ p.

2. Buckley J. J. C. : On the development, in Culicoides furens Poey, of Filaria (= Mansonella) ozzardi Manson, I897. J. Helminthol., I934, I 2, 99-118.

3. Chabaud A. G., Anderson R. C. : Nouvel essai de classification des filaires (superfamille des Filarioidea). Ann. Parasitol. Hum. Comp., I959, 34, 64-87.

4. Chabaud A. G., Bain O. : La lignee Dipetalonema. Nouvel essai de classification. Ann. Parasitol. Hum. Comp., 1976, si, 365-397.

5. Chardome M., Peel E. : La répartition des filaires dans la région de Coquilhatville et la transmission de Dipetalonema streptocerca par Culicoides grahami. Ann. Soc. Belge Med. Trop., 1949, 29, 99-I I8.

6. Dunn F. L., Lambrecht F. L. : On some filarial parasites of South American primates, with a description of Tetrapetalonema tamarinae $\mathrm{n}$. $\mathrm{sp}$. from the Peruvian Tamarin Marmoset, Tamarinus nigricollis (Spix, 1823). J. Helminthol., 1963, 37, 261-286.

7. Esslinger J. H., GARDINeR C. H. : Dipetalonema barbascalensis sp. n. (Nematoda : Filaroidea) from the owl monkey, Aotus trivirgatus, with a consideration of the status of Parlitomosa zakii Nagaty, 1935. J. Parasitol., 1974, 60, roor-1005.

8. FAUST E. C. : Human Helminthology. Ist ed. Lea and Febiger, Philadelphia, 1929.

9. FAUST E. C. : Notes on helminths from Panama. III. Filarial infection in the marmosets Leontocebus geoffroyi (Pucheron) and Saimiri orstedii orstedii (Reinhardt) in Panama. Trans. Roy. Soc. Trop. Med. Hyg., 1935, 28, 627-634.

io. Lowrie R. C., JR., Eberhard M. L., Orihel T. C. : Development of Tetrapetalomena marmosetae to the infective stage in Culicoides hollensis and C. furens. J. Parasitol., 1978, 64, 10031007 .

II. Lowrie R. C., JR., Orihel T. C., Eberhard M. L. : Culicoides variipennis, a laboratory vector for the Amazon form of Mansonella ozzardi. Am. J. Trop. Med. Hyg., 1982, 31, 166-167.

I2. Mullin S. W., ORinel T. C. : Tetrapetalonema dunni sp. n. (Nematoda : Filarioidea) from Malaysian tree shrews. J. Parasitol., 1972, s8, 1047-1051.

13. Nagaty H. F. : Parlitomosa zakii (Filariinae), a new genus and species and its microfilaria from Leontocebus rosalia. J. Egypt. Med. Assoc., 1935, I8, 483-496.

I4. ORIHEL T. C., EBerhaRD M. L. : Mansonella ozzardi : A redescription with comments on its taxonomic relationships. Am. J. Trop. Med. Hyg., 1982, 31, II42-I 147 .

r5. PRICE D. L. : Description of Dipetalonema interstitium $\mathrm{n}$. sp. from the grey squirrel and Dipetalonema llewellyni $\mathrm{n}$. sp. from the raccoon. Proc. Helm. Soc., I962, 29, 77-82.

16. Tidwell M. A., TIDwell M. A. : Development of Mansonella ozzardi in Simulium amazonicum, $S$. argentiscutum and Culicoides insinuatus from Amazonas, Colombia. Am. J. Trop. Med. Hyg., I982, 3I, II37-II4I.

I7. Sharp N. A. D. : Filaria perstans, its development in Culicoides austeni. Trans. Roy. Soc. Trop. Med. Hyg., 1928, 21, 371-396.

18. Uni S. : Filarial parasites from the black bear of Japan. Ann. Parasitol. Hum. Comp., 1983, S $8,7 \mathrm{I}-84$.

I9. YAtes Y. A., Lowrie R. C., JR., EBerhard M. L. : Development of Tetrapetalonema llewellyni to the infective stage in Culicoides hollensis. J. Parasitol., 1982, 68, 293-296.

20. YEH L. S. : On a filarial parasite, Deraiophoronema freitaslenti n. sp., from the giant anteater, Myrmecophaga tridactyla from British Guiana, and a proposed reclassification of Dipetalonema and related genera. Parasitology, 1957, 47, 196-205. 